\title{
A new species of Paracedicus Fet, 1993 from Iran (Aranei: Cybaeidae)
}

\section{Новый вид Paracedicus Fet, 1993 из Ирана (Aranei: Cybaeidae)}

\author{
Omid Mirshamsi ${ }^{1,2}$ \\ О. Миршамси ${ }^{1,2}$
}

\begin{abstract}
${ }^{1}$ Department of Biology, Faculty of Sciences, Ferdowsi University of Mashhad, Mashhad, Iran
${ }^{2}$ Research Department of Zoological Innovations (RDZI), Institute of Applied Zoology, Faculty of Sciences, Ferdowsi University of Mashhad, Mashhad, Iran; E-mail: mirshams@um.ac.ir
\end{abstract}

\begin{abstract}
KEY WORDS: spider, fauna, Iranian Plateau, description.
КЛЮЧЕВЫЕ СЛОВА: паук, фауна, иранское плато, описание.
\end{abstract}

ABSTRACT. A new species - Paracedicus darvishi sp.n. $\left(\sigma^{7}\right)$ - is described from the holotype male from north-eastern Iran. A detailed morphological description and illustrations of the new species are provided. The new species is closely related to P. gennadii Fet, 1993 and P. feti Marusik et Guseinov, 2003.

How to cite this article: Mirshamsi O. 2018. A new species of Paracedicus Fet, 1993 from Iran (Aranei: Cybaeidae) // Arthropoda Selecta. Vol.27. No.4. P.344 347. doi: 10.15298/arthsel. 27.4.11

РЕЗЮМЕ. Новый вид — Paracedicus darvishi sp.n. $\left(\sigma^{7}\right)$ - описан по самцу-голотипу из северовосточного Ирана. Даны детальное морфологическое описание и рисунки нового вида. Новый вид близок к P. gennadii Fet, 1993 и $P$. feti Marusik et Guseinov, 2003.

\section{Introduction}

Fet [1993] described Paracedicus as a subgenus of Cedicus Simon, 1875, which was later elevated to the genus rank by Marusik \& Guseinov [2003]. Based on the available taxonomic literature [Kishida, 1955; Lehtinen, 1967; Levy, 1996; Marusik, Guseinov, 2003; Zamani, Marusik, 2017], there is no consensus on to which family this genus belongs, either Cybaeidae or Desidae. Recently, reasoning from the unique conformation of the male bulb [Marusik, Guseinov, 2003; Zamani, Marusik, 2017], this genus, as well as the genera Cedicus and Cedicoides Charitonov, 1946, has been transferred to the family Desidae. However, the latter taxonomic act was not accepted by the World Spider Catalog [WSC, 2018] because the geographical range of Paracedicus did not fit with the family distribution given by Wheeler et al. [2017]. In this paper, the family assignment of Paracedicus follows the WSC [2018]. It seems, however, that detailed integrative studies based both on morphological and on molecular evidences are required to further clarify the taxonomic position of this genus.
In Iran, Paracedicus is known by two species that were recently recorded and/or described: viz., $P$. gennadii Fet, 1993 [Zamani et al., 2016] and P. kasatkini Zamani et Marusik, 2017 (Fig. 3). In the present paper, a new species from Iran is described. Thus, a number of the described/recorded Paracedicus species from Iran is risen to three (Map).

\section{Material and methods}

The illustrations were produced by means of an Olympus DP-71 camera attached to an Olympus SZH10 stereomicroscope at the Ferdowsi University of Mashhad. In order to provide a complete depth of field, several digital images were combined using the Zerene Stacker focus stacking software. All measurements are in $\mathrm{mm}$. Lengths of leg segments were measured on their dorsal side, and are given in the following sequence: total (femur, patella, tibia, metatarsus, and tarsus). The holotype male is deposited in the

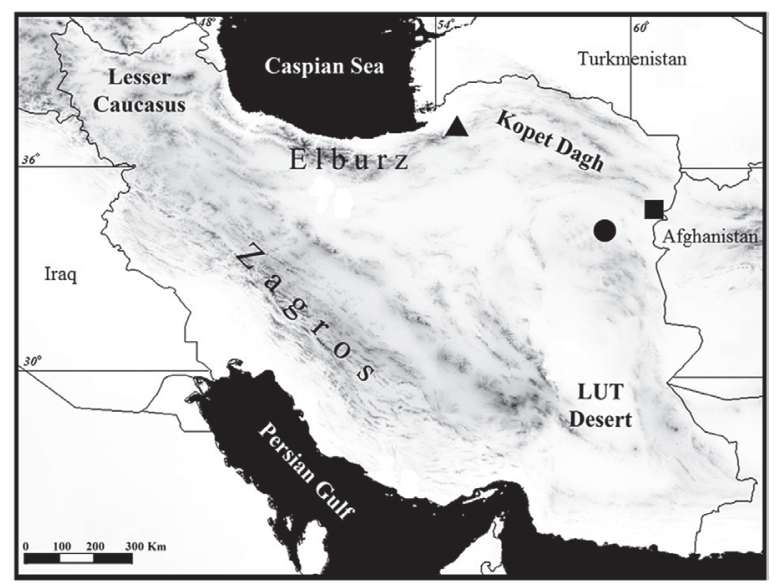

Map. Collecting localities of Paracedicus species in Iran: $P$. darvishi sp.n. (triangle), $P$. gennadii Fet, 1993 (square), and $P$. kasatkini Zamani et Marusik, 2017 (circle).

Карта. Точки находок видов Paracedicus в Иране: P. darvishi sp.n. (треугольник), P. gennadii Fet, 1993 (квадрат), and $P$. kasatkini Zamani et Marusik, 2017 (кружок). 


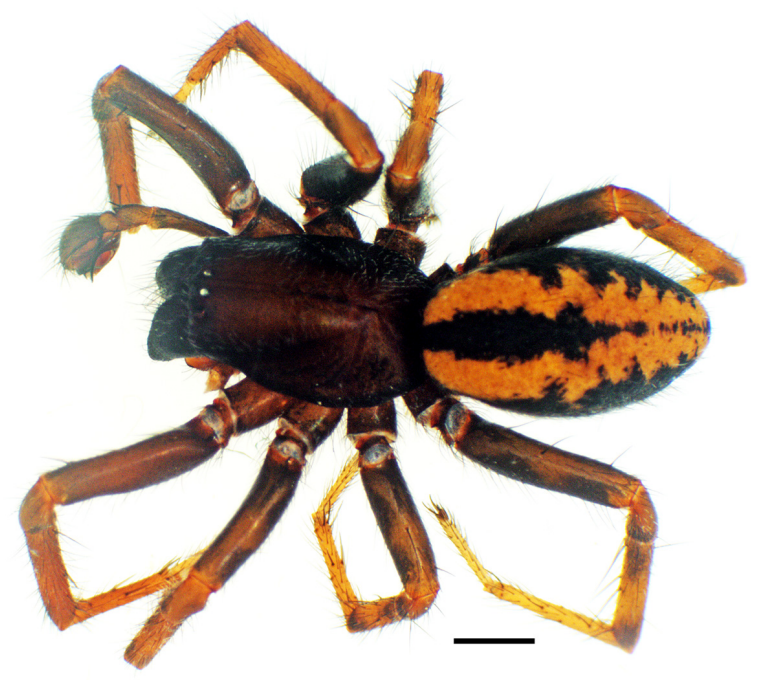

Fig. 1. Dorsal view of the holotype of P. darvishi sp.n. Scale bar $1 \mathrm{~mm}$.

Рис. 1. Голотип P. darvishi sp.n., вид сверху. Масштаб 1 мм.

Zoological Museum of the Ferdowsi University of Mashhad, Iran (ZMFUM). Abbreviations used in the text are as follows: ALE — anterior lateral eyes; AME - anterior median eyes; PLE — posterior lateral eyes; PME - posterior median eyes.

\section{Description}

\section{Paracedicus darvishi sp.n. Figs 1-6, Map.}

TYPE. Holotype $\sigma^{7}$ (ZMFUM) from Iran, Razavi Khorasan Province, Gonabad County, Kakhk ( $\left.34^{\circ} 08^{\prime} 59^{\prime \prime} \mathrm{N}, 58^{\circ} 38^{\prime} 21^{\prime \prime} \mathrm{E}\right)$, under stone on a sandy-clay substrate, 20.03.2015, O. Mirshamsi.

ETYMOLOGY. The species name is a patronym honoring the late Prof. Dr Jamshid Darvish (1952-2017) of the Ferdowsi University of Mashhad (Iran) for his great contributions to zoology and biosystematic studies in Iran. He was the first who introduced the author to the amazing world of spiders.

DIAGNOSIS. $P$. darvishi sp.n. is closely related to $P$. gennadii known from Iran and Turkmenistan (Fig. 5) and $P$. feti Marusik et Guseinov, 2003 known from Azerbaijan (Fig. 6), but can easily be distinguished from both by the following characters: the oval tegulum; the long and lanceolate conductor, not bending downward; the long, slightly curved embolus, with a wide embolic base; the very small median apophysis; and the absence of tooth between patellar apophyses (Figs 2-4). From the generotype - P. ephthalitus (Fet, 1993) - the new species can be separated by the oval tegulum, the reduced median apophysis and the shape of conductor.

COMMENTS. Zamani \& Marusik [2017] described $P$. kasatkini from the female collected from Golestan Province in northern Iran (Map). This species reliably differs from all the congeners in having no abdominal pattern, which is typical of all other Paracedicus species, including P. darvishi sp.n. Therefore, based on the unique coloration of P. kasatkini and a significant geographic distance of its type locality from that of $P$. darvishi sp.n. (c. $500 \mathrm{~km}$, see Map), these two taxa could not be conspecific.

DESCRIPTION. MALE. Body length (without chelicerae) 5.65; carapace 2.61 long, 1.84 wide. Eye sizes and interdistances: ALE 0.12, AME 0.07, PLE 0.09, PME 0.08, AME-AME 0.056, PME-PME 0.124. Sternum 1.48 long, 1.07 wide. Leg I: 7.19 (2.13, 0.9, 1.71, 1.55, 0.9). General appearance as in Fig. 1. Carapace dark brown, with dark margins; Chelicera dark brown, darker than carapace; Sternum dark brown. Endites and labium reddish brown, lighter in their frontal margins. Opisthosoma dark brown, with a distinct median colour pattern as in Fig. 1; venter dark brown, with scattered greyish markings. Spinnerets brown. Coxa and femora of all legs light reddish brown and slightly lighter than carapace. Trochanters and tibiae of all legs light brown. Metatarsi and tarsi of all legs yellowish brown. Legs with numerous spines, the leg spination as in Table.

Palp as in Figs 2-3, with two elongate and pointed patellar apophyses (Fig. 4), without the patellar tooth, tegulum oval, long conductor with a lanceolate tip, conductor started in the mid-part of tegulum, with long and straight embolus, not curved apically, embolic base wide, median apophysis very small, cymbium tip short and rounded.

Female unknown.

DISTRIBUTION. The type locality only (Map).

ACKNOWLEDGEMENTS. Financial support for this study was provided by the office of research affairs of the Ferdowsi University of Mashhad, which is gratefully acknowledged. I am deeply obliged to Dr Yuri M. Marusik (Magadan, Russia) and an anonymous referee for useful suggestions helping to improve the paper.

\section{References}

Fet V.Ya. 1993. The spider genus Cedicus Simon 1875 (Arachnida, Aranei, Agelenidae) from Middle Asia // Arthropoda Selecta. Vol.2. No.1. P.69-75.

Kishida K. 1955. A synopsis of spider family Agelenidae // Acta Arachnologica. Vol.14. No.1. P.1-13.

Lehtinen P.T. 1967. Classification of the cribellate spiders and some allied families, with notes on the evolution of the suborder Araneomorpha // Annales Zoologici Fennici. Vol.4. No.3. P.199-468.

Table. Leg spination in Paracedicus darvishi sp.n. Таблица. Вооружение ног у Paracedicus darvishi sp.n.

\begin{tabular}{|l|c|c|c|c|}
\hline & Femur & Patella & Tibia & Metatarsus \\
\hline I & $2 \mathrm{~d} 1 \mathrm{p}$ & - & $1 \mathrm{p} 6 \mathrm{v}$ & $1 \mathrm{p} \mathrm{6v}$ \\
\hline II & $2 \mathrm{~d} 1 \mathrm{p}$ & - & $4 \mathrm{v}$ & $1 \mathrm{p} 6 \mathrm{v}$ \\
\hline III & $2 \mathrm{~d} 1 \mathrm{p}$ & $1 \mathrm{p} 1 \mathrm{r}$ & $1 \mathrm{~d} 2 \mathrm{p} 1 \mathrm{r} 6 \mathrm{v}$ & $2 \mathrm{r} 6 \mathrm{v}$ \\
\hline IV & $3 \mathrm{~d}$ & $1 \mathrm{p} 1 \mathrm{r}$ & $2 \mathrm{r} 6 \mathrm{v}$ & $1 \mathrm{p} 2 \mathrm{r} 6 \mathrm{v}$ \\
\hline
\end{tabular}



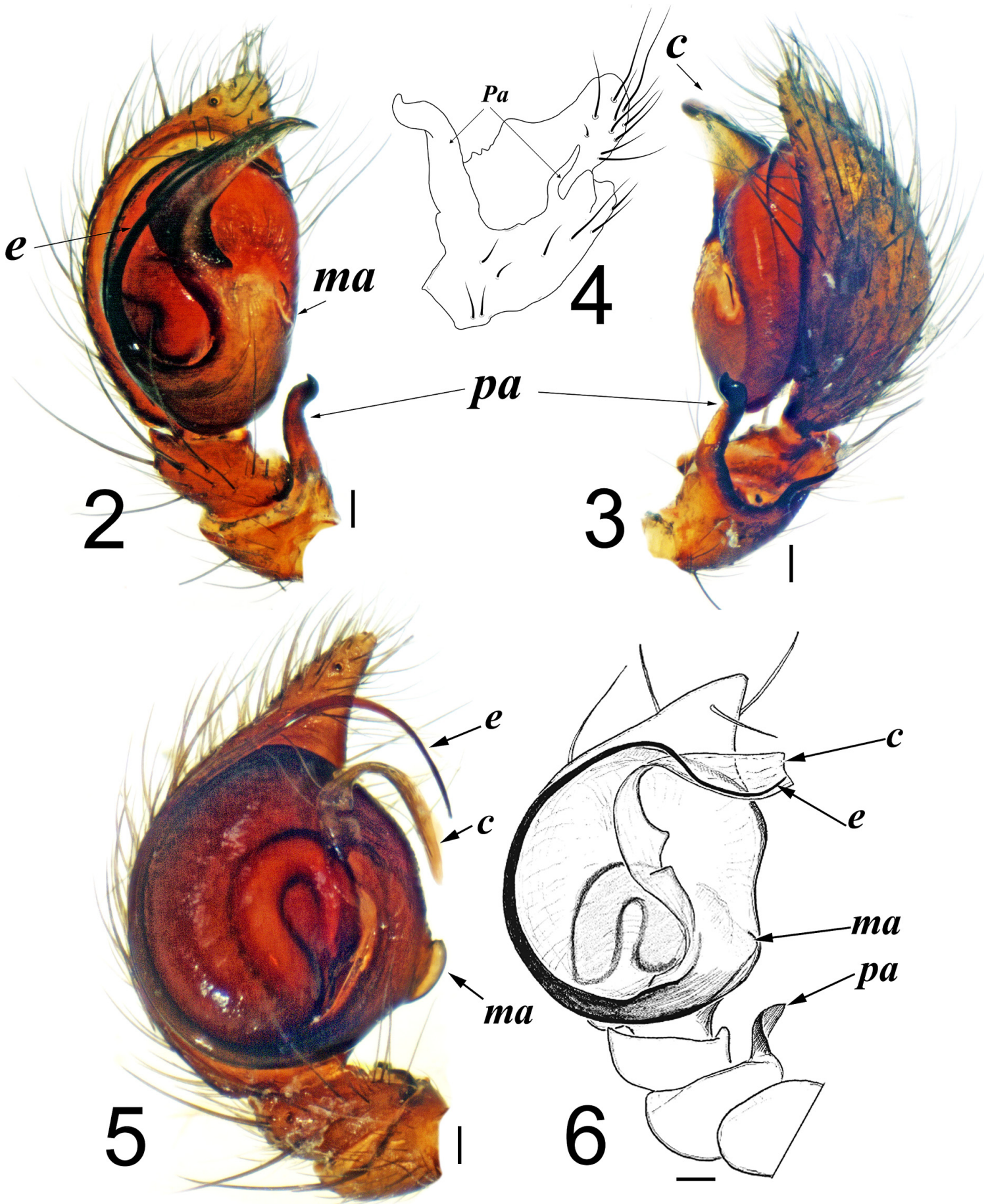

Figs 2-6. Male palps of Paracedicus species: P. darvishi sp.n. (2-4); P. gennadii Fet, 1993 (5, after Zamani et al. [2016]); P. feti Marusik et Guseinov, 2003 (6, after Marusik \& Guseinov [2003]): 2, 5, 6 - ventral view; 3 - retrolateral view; 4 — patellar apophyses. Scale bars: $0.1 \mathrm{~mm}$. Abbreviations: $c$ - conductor; $e$ - embolus; $m a$ - median apophysis; $p a$ - patellar apophysis.

Рис. 2-6. Пальпы самцов видов Paracedicus: P. darvishi sp.n. (2-4); P. gennadii Fet, 1993 (5, по Zamani et al. [2016]); P. feti Marusik et Guseinov, 2003 (6, по Marusik \& Guseinov [2003]): 2, 5, 6 - вид снизу; 3 - вид сзади-сбоку; 4 - отростки голени. Масштаб: 0,1 мм. Сокращения: $c$ - кондуктор; $e-$ эмболюс; $m a-$ медиальная апофиза; $p a$ - голенный отросток. 
Levy G. 1996. The agelenid funnel-weaver family and the spider genus Cedicus in Israel (Araneae, Agelenidae and Cybaeidae) // Zoologica Scripta. Vol.25. No.2. P.85-122.

Marusik Yu.M., Guseinov E.F. 2003. Spiders (Arachnida: Aranei) of Azerbaijan. 1. New family and genus records // Arthropoda Selecta. Vol.12. No.1. P.29-46.

Wheeler W.C., Coddington J.A., Crowley L.M., Dimitrov D., Goloboff P.A., Griswold C.E., Hormiga G., Prendini L., Ramírez M.J., Sierwald P., Almeida-Silva L.M., Álvarez-Padilla F., Arnedo M.A., Benavides L.R., Benjamin S.P., Bond J.E., Grismado C.J., Hasan E., Hedin M., Izquierdo M.A., Labarque F.M., Ledford J., Lopardo L., Maddison W.P., Miller J.A., Piacentini L.N., Platnick N.I., Polotow D., Silva-Dávila D., Scharff N., Szûts T., Ubick D., Vink C., Wood H.M., Zhang
J.X. 2017. The spider tree of life: phylogeny of Araneae based on target-gene analyses from an extensive taxon sampling // Cladistics. Vol.33. No.6. P.576-616. doi:10.1111/cla.12182.

WSC 2018. World Spider Catalog. Version 19.5. Natural History Museum Bern, online at: http://wsc.nmbe.ch, accessed on 31 August 2018. doi: 10.24436/2

Zamani A., Mirshamsi O., Rashidi P., Marusik Yu. M., Moradmand M., Bolzern A. 2016. New data on the spider fauna of Iran (Arachnida: Aranei), part III // Arthropoda Selecta. Vol.25. No.1. P.99-114.

Zamani A., Marusik Yu.M. 2017. Six new species of spiders (Arachnida: Araneae) from Iran // Oriental Insects. Vol.51. No.4. P.313-329.

Responsible editor D.V. Logunov 